\title{
UPAYA PEMAHAMAN PANTUN PADA MATA PELAJARAN BAHASA INDONESIA DENGAN MENGGUNAKAN LAGU “RASA SAYANGE"
}

\author{
Rini Damayanti ${ }^{1^{*}}$ \\ ${ }^{1}$ Program Studi PBSI Universitas Wijaya Kusuma Surabaya \\ Jalan Dukuh Kupang XXV No 54, Kota Surabaya, Indonesia \\ ${ }^{*}$ Corresponding Author : rinidamavanti fbs@uwks.ac.id
}

\section{Info Artikel Abstract}

Sejarah Artikel:

Diterima: $18 / 06 / 2020$

Direvisi: 26/06/2020

Disetujui:27/06/2020

Keywords: Sayange, song music, poetry
This study describes the application of Rasa Sayange song music in improving students' understanding in learning Indonesian poetry. The research method uses qualitative descriptive. This research is based on problems in schools, especially students in third grade of Muhammadiyah Karangharjo Elementary School, who have difficulty in understanding rhymes and creating a rhymes in learning Indonesian. From this research, it can be concluded that the Music of Rasa Sayange Song is an effective method for increasing rhymes understanding for students in Indonesian subjects. The Rasa Sayange Music Method is the right method to arouse students' interest in learning, activating and creating students.

\begin{abstract}
Abstrak
Penelitian ini mendeskripsikan penerapan musik lagu Rasa Sayange dalam meningkatkan pemahaman peserta didik dalam pembelajaran pantun Bahasa Indonesia. Metode penelitian menggunakan deskripstif kualitatif. Penelitian ini didasarkan pada permasalahan yang muncul di sekolah khususnya Siswa kelas III SD Muhammadiyah Karangharjo, yang mengalami kesulitan dalam memahami materi pantun dan menciptakan sebuah pantun dalam pembelajaran Bahasa Indonesia. Dari penelitian ini dapat ditarik simpulan Musik Lagu Rasa Sayange adalah metode yang efektif untuk meningkatkan pemahaman pantun bagi siswa pada mata pelajaran Bahasa Indonesia. Metode Musik Lagu Rasa Sayange adalah metode yang tepat untuk membangkitkan minat belajar siswa, mengaktifkan dan mengkreatifkan siswa.
\end{abstract}

\footnotetext{
"Alamat korespondensi:

Program Studi Pendidikan Bahasa dan Sastra Indonesia

Fakultas Bahasa dan Sains

Universitas Wijaya Kusuma Surabaya

Jl Dukuh Kupang XXV No 54, Kota Surabaya, Jawa Timur

E-mail: rinidamavanti fbs@uwks.ac.id

(C) 2020 Program Studi PGSD Universitas Flores Email: primagistrauniflor@gmail.com
} 


\section{PENDAHULUAN}

Pada hakekatnya siswa sekolah dasar sedang pada masa usia yang suka bermain dan bernyanyi. Oleh sebab itu, sebagai guru harus pandai-pandai mengambil peluang ini untuk menghasilkan anak didik yang aktif, kreatif, dan cerdas. Guna memenuhi tujuan di atas tentunya peran guru sangat penting baik dalam memilih metode maupun dalam strategi pembelajaran. Diupayakan usaha guru dapat menghasilkan prestasi belajar yang setidaknya memenuhi Standar Ketuntasan Minimal (SKM).

Hasil prestasi siswa dalam UNAS untuk bidang studi Bahasa Indonesia mengalami kemerosotan (Kompas, 2019). Berdasarkan pengamatan ternyata Bahasa Indonesia kurang diminati dan cenderung disepelekan. Demikian pun dari hasil angket yang peneliti bagikan membuktikan bahwa siswa cenderung menyepelekan dan kurang tertarik terhadap Bahasa Indonesia. Dari 33 responden yang peneliti beri angket 20\% (7 anak) mengatakan mudah dan tidak perlu belajar, $10 \%$ (4 anak) berpendapat kurang seru, 45\% (14 anak) membosankan, 25\% (8 anak) mengatakan terlalu rumit. Rendahnya minat siswa terhadap Bahasa Indonesia tentunya mempengaruhi prestasi belajar sehingga hasil pembelajaran rendah.

Hal ini merupakan tantangan bagi guru sebagai pendidik di dalam kelas. Seorang guru diharuskan mengembangkan kreatifitasnya dan mencari-cari metode yang sesuai dengan materi yang akan diajarnya sehingga akan membawa suasana aktif, dan menyenangkan. Guru pun harus mampu memahami kondisi siswa, lingkungan, permainan siswa, kecenderungan siswa, kondisi orang tua siswa, mata pelajaran siswa, keberhasilan, dan kegagalan siswa.

Menurut Irianto \& Subandi (2015), kebahagiaan adalah suatu konsep yang menggambarkan kondisi individu yang mengarahkan perasaannya kepada sesuatu yang positif dan memaknai peristiwa-peristiwa yang dialami dalam kehidupannya. Hati yang memiliki suasana gembira akan memudahkan penyerapan informasi yang diberikan oleh guru. Pemerolehan informasi dalam suasana yang menyenangkan biasanya akan tahan lebih lama dibandingkan informasi yang diperoleh dengan cara hafalan.

Kemampuan guru dalam memilih metode yang tepat sesuai karakter kelas akan menarik siswa sehingga siswa akan lebih cepat dan mudah dalam hal menangkap informasi yang disampaikan oleh guru. Adapun permasalahan yang timbul adalah sebagai berikut: rendahnya nilai siswa pada mata pelajaran Bahasa Indonesia, rendahnya minat siswa pada mata pelajaran ini, dan kurangnya kreatifitas guru dalam mencari metode yang dapat mengaktifkan dan mengkreatifkan siswa.

Adapun rumusan masalahnya sebagai berikut: Bagaimana penerapan musik lagu Rasa Sayange meningkatkan pemahaman siswa dalam pembelajaran pantun Bahasa Indonesia?

\section{METODE PENELITIAN}

Penelitian ini menggunakan metode
deskriptif kualitatif. Satori mengungkapkan penelitian kualitatif dilakukan karena peneliti ingin mengeksplor fenomena yang tidak dapat dikuantitatifkan yang bersifat deskripstif seperti proses suatu langkah kerja, dan lain sebagainya. Selain itu, Sugiono (2016) juga mengemukakakn penelitian kualitatif merupakan metode penelitian yang berlandaskan pada filsafat postpositivisme, digunakan untuk meneliti pada kondisi objek alamiah, peneliti adalah sebagai instrument kunci, teknik pengumpulan data dengan triangulasi, analisis data bersifat induktif atau kualitatif.

Penelitian ini muncul karena ada permasalahan mengenai pantun karya siswa di sekolah khususnya Siswa kelas III SD Muhammadiyah Karangharjo, yang mengalami kesulitan dalam memahami materi pantun dan menciptakan sebuah pantun dalam pembelajaran Bahasa Indonesia.

Subjek yang diteliti siswa kelas III yang terdiri atas 33 siswa. Hal ini didasarkan wawancara dengan guru kelas III SD Muhammadiyah Karangharjo, Syafrudin Nugroho, S.Pd yang merasa kesulitan mengajarkan Pantun pada siswa kelas III.

Pada penelitian ini, peneliti lebih memfokuskan pada penciptaan pantun karya 
siswa kelas III SD Muhammadiyah Karangharjo secara lisan. Oleh karena itu, peneliti akan mencari tahu dan mendalami karakteristik karya siswa yang diinterpretasikan dalam sebuah pantun melalui struktur pembentukannya diiringi musik Rasa Sayange.

Instrument penelitian yang utama adalah peneliti sendiri. Instrument disesuaikan dengan kebutuhan penelitian, kemudian disesuaikan dengan jenis data yang ingin diperoleh peneliti. Adapun instrument yang digunakan untuk mengambil data dalam penelitian ini, yakni dengan lembar observasi yang menugaskan siswa untuk membuat pantun. Tes tulis ini dilakukan peneliti berupa perintah secara verbal atau dilisankan.

Pada penelitian ini, teknik pengumpulan data yang digunakan teknik tes. Teknik tes dilakukan peneliti guna mendapatkan objek penelitian. Namun tes ini tidak dugunakan untuk mengukur peningkatan atau pengembangan kemampuan siswa secara kuantitas dalam menulis pantun. Teknik tes dilakukan guru melalui pertemuan secara langsung dengan subjek penelitian. Kegiatan ini dilaksanakan pada tanggal 11 Februari 2020 dengan agenda pemberian tugas pembuatan pantun.

\section{HASIL DAN PEMBAHASAN}

Penelitian ini menggunakan model pengajaran langsung. Pemikiran mendasar dari model pengajaran langsung adalah bahwa siswa belajar dengan mengamati secara selektif, mengingat, dan menirukan tingkah laku gurunya.

Peneliti menerapkan metode Brain Gym dengan didukung musik lagu Rasa Sayange. Menurut Wahyuningsih, Sugianto \& Wardiningsih (2019) Brain Gym dapat memberikan pengaruh positif pada peningkatan konsentrasi, atensi, kewaspadaan dan kemampuan fungsi otak untuk melakukan perencanaan, respon dan membuat keputusan.

Pertama, peneliti memberikan pendahuluan untuk memperkenalkan Brain Gym atau senam otak kepada siswa. Peneliti mendemonstrasikan langkah demi langkah gerakan yang harus dilakukan, kemudian meminta siswa supaya menirukan gerakan ini.
Pada awal pertemuan, gerakan ini diulang beberapa kali sampai siswa merasa relaks kemudian dilanjutkan dengan proses pembelajaran sesuai perencanaan.

Dalam kegiatan proses belajar mengajar, guru memiliki banyak variasi metode. Metode yang baik adalah metode yang mampu menggiring siswa ke arah yang positif: siswa dapat lebih aktif, lebih kreatif dalam pengembangan bahasa, dan memiliki kemampuan berpikir secara logis. Satu diantaranya adalah Brain Gym yaitu serangkaian gerakan tubuh yang sederhana yang digunakan untuk memadukan semua bagian otak untuk meningkatkan kemampuan belajar dan rasa kebersamaan. Disini peneliti memberikan instruksi gerakan yang harus diikuti. Siswa secara bersama-sama mencoba melakukan setiap gerakan yang diinstruksikan. Masing-masing gerakan yang dilakukan memiliki tujuan yang berbeda.

Pada intinya Brain Gym adalah senam otak yang digunakan untuk melatih kerja otak secara bersamaan sehingga baik otak kanan maupun kiri dapat bekerja dengan baik. Dalam hal pembuatan pantun, peneliti menerapkan metode musik Lagu Rasa Sayange sebagai sebuah pendekatan dalam memahami dan menciptakan pantun.

Jumaryatun (2014) menyatakan lagu atau musik dapat meningkatkan intelegensi karena rangsangan ritmis mampu meningkatkan fungsi kerja otak manusia, seperti membuat saraf-saraf otak bekerja serta menciptakan rasa nyaman dan tenang sehingga fungsi kerja otak menjadi optimal. Musik merupakan satu aspek penting dalam hidup manusia. Musik dapat mempengaruhi seluruh aktifitas otak. Musik banyak menimbulkan pengaruh positif dalam diri seseorang. Satu di antaranya musik merangsang kreativitas, kepekaan, dan kemampuan berfikir. Belajar dengan menggunakan musik yang tepat akan membantu dalam meningkatkan daya ingat. Untuk itulah musik lagu Rasa Sayange dipilih dalam penelitian ini sebagai metode dalam pemahaman pantun.

Dikarenakan belum adanya referensi tentang metode musik maka peneliti mencoba mendeskripsikan metode musik sebagai sebuah 
metode yang digunakan untuk merangsang daya ingat melalui musik lagu yang didengar. Dengan mendengar musik lagu rasa sayange siswa dapat mengingat kembali syair lagu sekaligus bunyi bahasa yang termuat di dalamnya. Sehingga rangkaian kata yang berhasil diingat akan membantu siswa membatasi jumlah suku kata yang menjadi rangkaian pada pantun.

\section{Proses Pelaksanaan Pembuatan Pantun dengan Lagu Rasa Sayange}
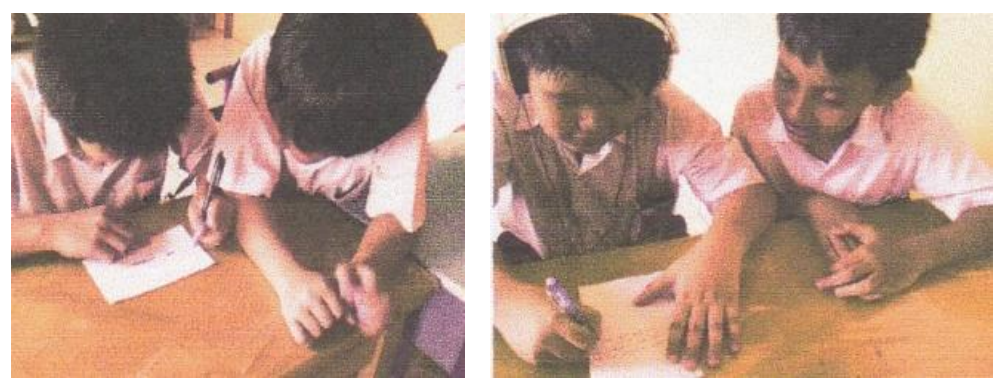

\section{Pelaksanaan Pembuatan Pantun}

1. Peneliti menyanyikan lagu Rasa Sayange dengan tempo normal dan membiarkan siswa mengikuti alunan syair lagu tersebut.

2. Menuliskan lirik lagu yang berhasil mereka himpun:

\section{Rasa Sayange}

Rasa sayang sayange

E.... lihat dari jauh

Rasa sayang sayange ...

\section{Kalau ada sumur di ladang}

Boleh kita menumpang mandi

Kalau ada umurku panjang

\section{Boleh kita berjumpa lagi}

Kemudian peneliti mencoba memancing siswa untuk melihat kembali lirik lagu tersebut. Ciri-ciri apa saja yang ditemukan dalam syair lagu di atas.

3. Setelah siswa menemukan cirinya kemudian siswa mencoba mengganti syair lagu tersebut sesuai kreatifitas mereka. Banyaknya suku kata yang mereka

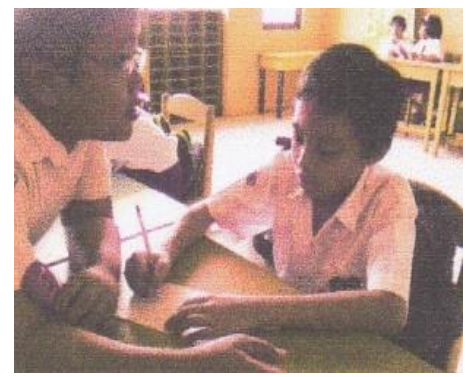

Peneliti menerapkan metode Brain Gym dengan didukung lagu Rasa Sayange. Pertama, peneliti memberikan pendahuluan untuk memperkenalkan Brain Gym atau senam otak kepada siswa. Peneliti mendemonstrasikan langkah demi langkah gerakan yang harus dilakukan, kemudian meminta siswa supaya menirukan gerakan ini. Pada awal pertemuan, gerakan ini diulang beberapa kali sampai anak merasa relaks kemudian dilanjutkan dengan proses pembelajaran sesuai perencanaan.

ciptakan secara otomatis mengacu pada lirik lagu Rasa Sayange.

4. Syair lagu yang berhasil mereka buat otomatis menjadi bait sebuah pantun. Untuk mencermati keberhasilan siswa, mereka secara bergantian menyanyikan lagu Rasa Sayange dengan lirik hasil ciptaan masing-masing siswa. Siswa yang belum mendapatkan giliran bertugas mencermasti ketepatan rima dan jumlah suku kata.

5. Dengan mengenal bentuk pantun maka pada tahap terakhir siswa berhasil memberikan kritikan dan komentar terhadap hasil karya teman yang kurang sesuai dengan ciri pantun.

6. Siswa secara aktif menemukan banyak pengalaman dalam penciptaan sebuah pantun.

\section{SIMPULAN DAN SARAN}

Setelah melakukan proses tahap demi tahap penelitian, dapatlah ditarik simpulan sebagai berikut: Lagu Rasa Sayange adalah metode yang dapat dugunakan untuk meningkatkan pemahaman pantun bagi siswa pada mata pelajaran Bahasa Indonesia. Lagu Rasa Sayange adalah metode yang tepat untuk 
membangkitkan minat belajar siswa, mengaktifkan dan mengkreatifkan siswa.

\section{DAFTAR PUSTAKA}

Irianto, I., \& Subandi, S. (2015). Studi Fenomenologis Kebahagiaan Guru di Papua. Gadjah Mada Journal of Psychology (GamaJoP), 1(3).

Jumaryatun, J. (2014). Penggunaan media lagu sebagai upaya meningkatkan motivasi dan kemampuan menulis cerpen. BASASTRA, 1(3).

Kompas. (2019). Penggunaan Bahasa Indonesia Mengalami Degradasi. Edukasi-kompas.com. Diakses online pada tanggal 16 Juni 2020.

Satori, D. (2017) Metode Penelitian Kualitatif. Bandung : Alfabeta.

Sugiyono, S. (2016). Metode Penelitian Kualitatif, Kuantitatif dan $R \& D$. Bandung : Alfabeta.

Wahyuningsih, Baiq Yuni. (2019). Pelatihan Aktifitas Brain Gym untuk Peningkatan Konsentrasi Mahasiswa STMIK Mataram. EDISI. 1 (1). 155-162.

Wahyuningsih, B. Y., Sugianto, R., \& Wardiningsih, R. (2019). Pelatihan Aktivitas Brain Gym untuk Peningkatan Konsentrasi Mahasiswa STMIK Mataram. EDISI, 1(1), 155-162. 